\title{
Mısır Bitkisinin Verim Parametreleri ile Toprağın Bazı Fiziksel ve Kimyasal Özellikleri Arasındaki Regresyon Modellerin Belirlenmesi
}

\author{
Nalan KARS', \\ İmanverdi EKBERLi², * \\ 'Karadeniz Tarımsal Araștırma Enstitüsü Müdürlüğü, Samsun \\ ºndokuz Mayıs Üniversitesi, Ziraat Fak. Toprak Bilimi ve Bitki Besleme Bölümü, Samsun
}

\author{
*Sorumlu yazar e-mail (Corresponding author e-mail): iman@omu.edu.tr \\ Geliș tarihi (Received) : 10.09.2019 \\ Kabul tarihi (Accepted): 12.12.2019 \\ DOI: $10.21657 /$ topraksu.618118
}

\section{Öz}

Bu çalıșmanın amacı, Çarșamba Ovası'nda yetiștirilen mısır bitkisinin verim parametreleriyle (bitki boyu, bin tane ağırlığı ve tane verimi) toprakların bazı fiziksel ve kimyasal özellikleri arasında regresyon modellerin olușturulması ve elde edilen modellerin ova topraklarında bitki veriminin tahmininde uygulanabilirliğinin belirlenmesidir. Bu amaçla, ovanın çiftçiler tarafından mısır tarımı yapılan arazilerinden toprak ve bitki örnekleri alınmıștır. Araștırma alanındaki mısır bitki boyu değerlerinin \%65'i $250 \mathrm{~cm}$ ile $300 \mathrm{~cm}$, bin tane ağırlığı değerlerinin \%60'ı $300 \mathrm{~g}$ ile $460 \mathrm{~g}$, tane verimi değerlerinin \%57.5'i ise 1000-1400 kg da-1 arasında değiștiği saptanmıștır. Bitki boyu ile $\mathrm{Ca}+\mathrm{Mg}$, kireç $\left(\mathrm{CaCO}_{3}\right)$, hacim ağırlığı (HA), tarla kapasitesi $(\mathrm{TK})$, organik madde $(\mathrm{OM}),(\mathrm{EC})^{2},(\mathrm{OM})^{2},\left(\mathrm{CaCO}_{3}\right)^{2}, \sqrt{\mathrm{Kum}}, \sqrt{\mathrm{N}}$ parametreleri arasındaki regresyon modeli istatistiksel olarak anlamlı farklılık saptanmayıp, belirleme katsayısı (R = 0.543) orta; bin dane ağırlığı ile EC, $\mathrm{OM}, \mathrm{Kum},(\mathrm{HA})_{2},(\mathrm{KumxHA}), \sqrt{ } \mathrm{CaCO}_{3^{\prime}} \sqrt{ } \mathrm{EC}$, solma noktası (SN) parametreleri arasındaki model istatistiksel olarak anlamlı ( $P=0.012)$, belirleme katsayısı $(R=0.819)$ çok yüksek; tane verimi ile $O M, N$, fosfor $(P)$, potasyum (K), sodyum (Na), çinko (Zn), Ca+Mg, Silt, (SNxHA), HA, SN parametreleri arasındaki modelin performansı çok yüksek ( $R=0.894 ; p=0.001$ ) olarak belirlenmiștir. Verim parametreleri ile toprakların fiziksel ve kimyasal özellikleri arasındaki regresyon modellerin geçerliliğinin belirlenmesinde belirleme katsayısı (R), hata kareler ortalamasının karekökü (HKOK), uygunluk indeksi (d), modelin etkinliği (ME) birlikte değerlendirilmiștir. Elde edilen regresyon modellerin, ova topraklarında yetiștirilen mısır bitkisinin verim parametrelerinin tahmin edilmesinde uygulanabilirliği mümkün gözükmektedir.

Anahtar Kelimeler: Bitki boyu, bin tane ağılığı, fiziksel ve kimyasal toprak özellikleri, regresyon modeller, verim

\section{Applicability of Regression Models Between Yield Parameters and Some Soil Properties of Maize Plant}

\begin{abstract}
The aim of this study was to set regression models between yield parameters of maize plant grown in Çarșamba Plain (plant height, thousand seed weight and grain yield) and some physical and chemical properties of soils and to determine applicability of obtained models in estimation of yield in plain soils. For this purpose, soil and plant samples were taken from root zone of cultivated farms. In the research area, 65\% of the maize plant height values were determined as between $250 \mathrm{~cm}$ and 300
\end{abstract}

Nalan KARS: https://orcid.org/0000-0002-0609-0815

İmanverdi EKBERLi: https://orcid.org/0000-0002-7245-2458 
$\mathrm{cm}, 60 \%$ of thousand seed weight values were between $300 \mathrm{~g}$ and $460 \mathrm{~g}$, and $57.5 \%$ of the yield values were between 1000-1400 kg da'. In the regression model between maize plant height and electrical conductivity (EC), $\mathrm{Ca}+\mathrm{Mg}$, lime $\left(\mathrm{CaCO}_{3}\right)$, bulk density $(\mathrm{BD})$, field capacity $(\mathrm{FC})$, organic matter $(O M),(E C)^{2}$, $\sqrt{ }$ Sand, nitrogen $(\sqrt{ } N)$ content wasn't statistically significant $(R=0.543, p>005)$; in the model

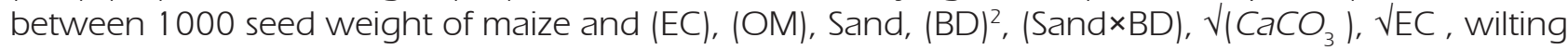
point (WP) parameters, the high determination coefficient $R=0.819$ was determined at statistical significance level of $p=0.012$; the performance of the model between maize grain yield and $O M, N$, phosphorus (P), potassium (K), sodium (Na), zinc (Zn), Ca+Mg, Silt, Sand, (BD×WP), BD, WP parameters was very high $(R=0.840 ; p=0.001)$. Determination coefficient $(R)$, root mean square error (RMSE), index of agreement (d), model efficiency (ME) were evaluated together to determine the validity of regression models between the yield components and physical and chemical properties of soils. In general, statistical parameters were within validity limits. It can be seen that the regression models obtained can be applied in the estimation of yield parameters of maize plant grown in plain soils.

Keywords: Plant height, physical and chemical properties of soils, regression models, thousand seed weight, yield

\section{Giriș}

Medeniyetlerin bașlangıcından beri artan nüfusa bağlı olarak birim alandan daha fazla ürün elde etmek amacıyla yapılan yoğun tarım uygulamaları (gübreleme, ilaçlama, sulama, toprak ișleme vb.) sonucunda, toprağın fiziksel, kimyasal ve biyolojik özelliklerinden birinin veya birkaçının yetișme ortamında yüksek veya eksik bulunması, bitki gelișimini ve bitkilerin toprakta bulunan besin maddelerinden yeteri kadar yararlanmasını sınırlandırmakta ve böylece yüksek ve kaliteli ürün alınmasını da olumsuz yönde etkilemektedir. Toprak verimliliğinin artırıması için gerekli yöntemlerinin belirlenmesinde, verim parametreleri ile toprak özellikleri arasındaki ilișkilerin incelenmesi önemlidir. Bu nedenle, araștırmacılar (Taban vd., 2004; Ekberli ve Kerimova, 2005; Özdemir vd., 2014; Ekberli ve Dengiz, 2016; 2017; Kars ve Ekberli, 2019b) tarafından toprakların fizikokimyasal özelliklerinin ve bu özelliklerle çeșitli bitkilerin verim parametreleri arasındaki ilișkinin belirlenmesi; verimliliğin korunması, tahmin edilmesi ve artırımasına yönelik yöntemlerin olușturulmasında gerekliliği vurgulanmıștır.

Mısır bitkisi diğer tahıl ürünleri ile beraber, ülkemizin ekonomi bağımsızlığında önemli olup, mısırın ekiliș alanı 6.8 × 105 ha, üretimi 6.4 × 106 ton, verimi ise $941 \mathrm{~kg} \mathrm{da}^{-1}$ olmaktadır. Karadeniz bölgesinde en önemli tarımsal potansiyele sahip olan Çarșamba Ovası́nda, mısır bitkisinin ekiliș alanı 4038 ha, üretimi 27021 ton, verimi $750 \mathrm{~kg} \mathrm{da}^{-1}$ 'dır (Anonim, 2016). Mısır diğer kültür bitkilerine oranla (pamuk, buğday, çeltik gibi) güneș ıșığından daha

yüksek oranda yararlanmaktadır. Bu ise, daha fazla miktarda kuru madde olușumuna neden olmakta ve misır bitkisi toprakta mevcut olan besin maddelerinin daha iyi değerlendirerek birim alandan yüksek verim alınmasını sağlamaktadır (Colakoğlu, 1985). Birçok araștırmada (Tosun ve Yurtman, 1973; Park vd., 1986; Gençtan ve Sağlam, 1987; Korkut vd., 1993) mısır bitkisinin bin tane ağırlığının verimle pozitif yönde ilișkisinin olduğu, verim azaldığında bin tane ağırlığının da azaldığı bildirilmiștir. Özgentürk (2001)'e göre, bin tane ağırlığı, diğer agronomik faktörlerle beraber, tane verimine önemli düzeyde etki yapmaktadır. Yalçın ve Usta (1992), farklı tekstürlü 5 adet toprak üzerinde yaptıkları bir araștırmada, organik madde miktarının \%0.6-1.27 arasında değișiminin, mısır bitkisinin gelișimine negatif etki yapmadığını belirlemișlerdir. Sönmez (2001), 1998-1999 yıllarında Tokat Erbaa ilçesi ekolojik koșullarında farklı azot dozlarının mısır çeșitlerinde tane verimi ve verim parametrelerine etkisini incelemiș; azot dozlarının bitki boyu, koçan uzunluğu, koçan tane sayısı, koçan tane ağırlığı, bin tane ağırlığı ve tane verimi üzerine çok önemli etkisinin olduğunu belirlemiștir.

Regresyon modellerin ekoloji, hidroloji, çeșitli mühendislik dallarında olduğu gibi, tarım alanında da geniș uygulamaları vardır. Toprak biliminde toprak özelliklerine ait yeterli düzeyde değerlerin birikimine paralel olarak, regresyon modellerin amaca uygun olarak kullanımı ortaya çıkmıștır. Toprak ve bitki ekosisteminde regresyon modellerin 
yapılması ve kullanılması (Bayraklı vd., 1999; Korkmaz vd., 2000; Overman ve Scholtz, 2002; Gülser, 2004; Guber vd., 2009; Huang vd., 2014; Dorsey ve Hardy, 2018; Özdemir vd., 2018; Thiery vd., 2018; Kars ve Ekberli, 2019a); basit diferansiyel, cebirsel ve kısmi türevli diferansiyel denklemlerle ifade edilen teorik modellerden daha kolay ve pratik olmaktadır. Deneysel (regresyon) ve teorik modellerin yapılmasında, birçok varsayımlar kabul edilmekte, benzer etkilere sahip parametrelerin bazılarının kullanılması söz konusu olmaktadır (Bouma ve van Lanen, 1987; Bouma, 1989; Pachepsky ve Rawls, 2004). Regresyon modellerin yardımıyla, çeșitli bitkilerin verim parametreleri (bitki boyu, bin tane ağırlığı, tane verimi gibi) ile toprağın bazı fiziksel ve kimyasal özellikleri arasındaki nicel ilișkiler açıklanabilmektedir. Araștırmacılar tarafindan yapılan regresyon modellerinde bağımsız parametreler olarak; deneysel olarak daha kolay belirlenebilen kimyasal ve fiziksel toprak özellikleri tercih edilmektedir (Campbell ve Shiozawa, 1992; Vereecken vd., 2010; Gülser vd., 2016; Dengiz ve Ekberli, 2017). Regresyon modellerinin geçerliliğinin belirlenmesinde farklı istatistiksel parametrelerin kullanılması, model olușturulmasında önemli ve gerekli așamalardan biridir. Birçok araștırmacı tarafından regresyon modellerinin uygulanabilirliğini belirlemek için; hata kareler ortalamasının karekökü (HKOK), uygunluk indeksi (d), maksimum nisbi hata $(\mathrm{MNH})$, mutlak hata $(\mathrm{MH})$, belirleme katsayısı (R) gibi istatistiksel parametreler kullanılmıștır (Alexandrov ve Hoogenboom, 2000; Budka vd., 2015; Patil ve Singh, 2016; Aydoğan ve Soylu, 2017). Karadeniz bölgesinin en önemli tarımsal potansiyele sahip olan Çarșamba ovasında çeșitli bitkisel ürünler (buğday, soya, mısır, çeltik, findık vb.) yetiștirilmektedir. Bu bitkisel ürünlerin yetiștirildiği alanlarda toprak özelliklerinin ve bitkilerin agronomik özelliklerinin belirlenmesi, toprakların sürdürülebilirliğinin korunmasında ve ürün tahmininde önemlidir.

Bu araștırma; Çarșamba Ovası́nda geleneksel toprak ișleme yöntemiyle mısır yetiștirilen tarım topraklarının bazı fiziksel ve kimyasal özellikleri ile misır bitkisinin verim parametreleri (bitki boyu, bin tane ağırlığı ve tane verimi) arasındaki korelasyon ilișkilerine dayanarak, bu özellikler arasında regresyon modellerin olușturulması ve elde edilen modellerin ova topraklarında bitki veriminin tahmininde uygulanabilirliğinin belirlenmesi amacıyla yürütülmüștür.

\section{MATERYAL VE YÖNTEM}

Araștırma; 2013-2014 yıllarında Samsun ili Çarșamba Ovası́nı temsil eden 20 köyde, çiftçiler tarafindan tarım yapılan arazilerden $0-20 \mathrm{~cm}$ derinlikten rastgele örnekleme metodu ile Jackson (1962) tarafından bildirildiği șekilde her yıl için 20 toprak örneği alınarak gerçekleștirilmiștir. Aynı alanlardan bitki örneklerinin alınmasında ise Anonim (2013)'de gösterilen yöntem kullanılmıștır. Toprak ve bitki örneklerinin alındığı lokasyonlar Șekil l'de gösterilmiștir.

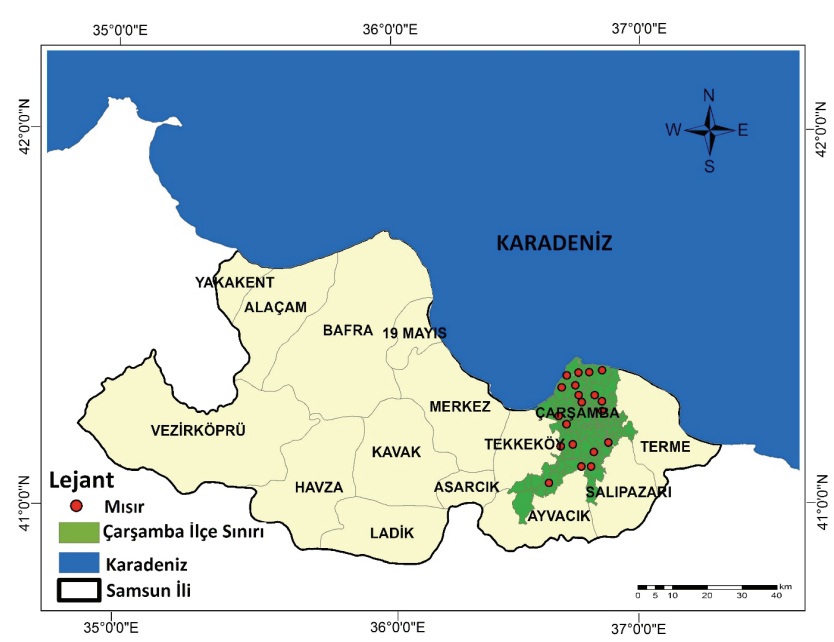

Șekil 1. Toprak ve bitki örneklerinin alındığı lokasyonlar

Figure 1. Locations where soil samples are taken

Samsun ili sınırları içerisinde yer alan Çarșamba Ovası, güneyde Canik dağları ile kuzeyde ise Karadeniz ile sınırı bulunan Yeșilırmak'ın olușturduğu bir delta ovasıdır. Ova 0-50 m kotları arasında, 103766 hektarlık bir alanı kapsamaktadır. Çarșamba Ovası doğu-batı istikametinde 65 km, güney-kuzey istikametinde ise $35 \mathrm{~km}$ uzunluğa sahiptir. Ova taban arazilerinin genel eğimleri güney-kuzey istikametinde olup ortalama eğim $\% 0.1$ 'dir. Bu eğim, deniz kenarına yaklaștıkça \%00.02'ye kadar düșmektedir. Yamaç arazilerde ise eğim, \%2-40 arasında değișmektedir. Ova; bitki örtüsü yönünden çok zengin olup, 58921 hektar tarım arazisine sahiptir. Ovada mısır bitkisinin ekiliș alanı 4038 ha, üretimi 27021 ton, verimi 750 $\mathrm{kg} \mathrm{da}^{-1}$ dır (Anonim, 2016). Ova toprakları alüviyal ve kısmen de kolüviyal (kestane rengi topraklar, gri-kestane podzolik topraklar, kahverengi orman toprakları) karakterdedir (Anonim, 1984). Ovada yıllık toplam yağıș miktarı 985.9 mm olup, yıllık sıcaklık ortalaması ise $15-17{ }^{\circ} C^{\prime}$ dir (Turan vd., 2018). 
Alınan toprak örneklerinde tekstür hidrometre yöntemiyle (Demiralay, 1993); hacim ağırlığı Demiralay (1993)'a göre; toprak reaksiyonu (pH), 1:1 oranındahazırlanantoprak-susüspansiyonunda cam elektrotlu $\mathrm{pH}$ metre ile (Bayraklı, 1987); elektriksel iletkenlik (EC), 1:1 oranında hazırlanan toprak-su süspansiyonunda elektriksel kondaktivite aleti ile (Richards, 1954); kireç $\left(\mathrm{CaCO}_{3}\right)$, Scheibler kalsimetresiyle volümetrik olarak (Kacar, 1994); organik madde (OM), Walkley-Black yaș yakma yöntemine göre (Kacar, 1994); toplam azot (N) Kjeldahl yaș yakma yöntemine göre (Kacar, 1994) belirlenmiștir. Toprakların yarayıșlı fosfor (P) içeriği, mavi renk yöntemine göre (Olsen vd., 1954); değișebilir potasyum (K) ve sodyum (Na), toprak örneğinin $1 \mathrm{~N}$ amonyum asetat $(\mathrm{pH}=7.0)$ çözeltisi ile ekstrakte edilmesiyle, kalsiyum (Ca) ve magnezyum (Mg) 0.01M EDTA titrasyonu ile (Sağlam, 1997); katyon değișim kapasitesi (KDK), Bower yöntemine göre (Anonymous, 1954); alınabilir demir (Fe), bakır (Cu), mangan ( $\mathrm{Mn}$ ) ve çinko (Zn) içerikleri ise Lindsay ve Norvell (1978) tarafından bildirildiği șekli ile (0.005 M DTPA + 0.01 $\left.\mathrm{M} \mathrm{CaCl}_{2}+0.1 \mathrm{M} \mathrm{TEA}, \mathrm{pH}=7.3\right)$ tespit edilmiștir. Tarla kapasitesi (TK) ve solma noktası (SN) değeri, basınçlı tabla aletinde sırasıyla 1/3 atm ve 15 atm basınç altında toprak örneklerinin hidrolik denge durumuna gelmesinden sonra ağırlık esasına göre (Black, 1965); bitkiye yarayıșlı su miktarı (BYS), TK ve SN arasındaki farktan hareketle hesap yolu ile belirlenmiștir. Mısır bitkisinde bitki boyu (BB), bin tane ağırlığı (BTA) ve tane verimi (TV) ölçümleri, Anonim (2013) tarafindan bildirilen esaslar çerçevesinde yapılmıștır.

\section{İstatistiksel analizler}

Toprak ve bitki analiz sonuçlarına ait tanımlayıcı istatistikler ile toprak özellikleri ve bitki verim parametreleri arasındaki korelasyonlar SPSS 17.0 paket programında hesaplanmıș, verim parametreleri ile toprak özellikleri arasında olușturulan regresyon modeller ise, Minitab 17.0 paket programında olușturulmuștur.

Hata kareler ortalamasını karekökü (HKOK), uygunluk indeksi (d), modelin etkinliği (ME) sırasıyla așağıdaki ifadeler kullanılarak hesaplanmıștır:

$$
H K O K=\sqrt{\frac{1}{n_{i=1}} \sum_{i}^{n}\left(x_{i}-y_{i}\right)^{2}}
$$

Burada, $n$-verilerin sayı ve ise , ise $m=n$; ölçülen; - hesaplanan değerlerdir.

$$
d=1-\frac{\sum_{i=1}^{n}\left(x_{i}-y_{i}\right)^{2}}{\sum_{i=1}^{n}\left(\left|x_{i}-\bar{y}\right|+\left|y_{i}-\bar{y}\right|\right)^{2}}
$$

Burada, ve sırasılyla hesaplanan ve ölçülen değerlerin ortalamasını iafade etmektedir.

$$
M E=1-\frac{\sum_{i=1}^{n}\left(x_{i}-y_{i}\right)^{2}}{\sum_{i=1}^{n}\left(y_{i}-\bar{y}\right)^{2}}
$$

Hata kareler ortalamasını karekökü (HKOK), tahmin hatalarının standart sapmasını ifade etmektedir. Uygunluk indeksi (d) modelin geçerliliğinin bir göstergesi olup, d'nin l'e yakın olması modelin uygulanabilirliğini göstermektedir. Krause vd., (2005) tarafından, deneysel hidrolojik modele yönelik bir araștırmada, ME değerlerinin 1 (mükemmel uyum) ile arasında değiștiği gösterilmiș; ME'nin sıfırdan küçük olması durumunda ise ölçülen ortalama değerin, hesaplanan değerden daha etkin olduğu belirtilmiștir. d ve ME'nin analitik ifadelerinin karșılaștırılmasından da görüldüğü gibi, genel olarak d değeri ME'den büyük olmaktadır (Willmott ve Matsuura, 2005; Willmott vd., 2012; Kumar vd., 2015; Wang vd., 2016).

\section{BULGULAR VE TARTIȘMA}

\section{Mısır bitkisinin agronomik özelliklerinin dağı̆ımı}

Araștırma alanında yetiștirilen mısır bitkisinin bazı agronomik özelliklerine ait bazı tanımlayıcı istatistikler Çizelge 1'de verilmiștir.

Tablo 1'den görüldüğü gibi, mısır bitkisinin BB, BTA ve TV değerleri sırasılyla; 172.33-351.22 $\mathrm{cm}, \quad 167.54-450.75 \mathrm{~g}$ ve $833.58-1584.37 \mathrm{~kg}$ $\mathrm{da}^{-1}$ arasında değișmekte, ortalama değerleri ise sırasıyla $294.16 \mathrm{~cm}, 345.19 \mathrm{~g}$ ve $1293.37 \mathrm{~kg} \mathrm{da}^{-1}$ olmaktadır. Görüldüğü gibi, istatistiksel göstergeler geçerli sınırlar dahilinde değișmektedir. Bitki boyu ve bin tane ağırlığına ait standart sapma değerleriyle karșılaștırıldığında tane veriminin standart sapmasının yüksek olmasının nedeni, tane veriminin geniș aralıkta değișimi olabilir. Çarpıklık değerleri ise, soldan sıfıra yakın olmakta, dolayısıyla dağılımın normale yakın olduğunu göstermektedir. 
Çizelge 1. Mısır bitkisinin bazı agronomik özelliklerine ait bazı tanımlayıcı istatistikler ( $n=40$ )

Table 1. Some descriptive statistics of some agronomic characteristics of maize plant $(n=40)$

\begin{tabular}{ccccccc}
\hline Özellikler & En düșük & En yüksek & Ortalama & St. Sapma & VK, \% & Carpıklık \\
\hline BB, cm & 172.33 & 351.22 & 294.16 & 32.85 & 11.16 & -1.639 \\
BTA, g & 167.54 & 450.75 & 345.19 & 63.59 & 18.42 & -0.274 \\
TV, kg da-1 $^{-1}$ & 833.58 & 1584.37 & 1293.53 & 173.05 & 13.37 & -0.621 \\
\hline
\end{tabular}

BB: Bitki boyu; BTA: Bin tane ağırık; TV: Tane verim; VK: Varyasyon katsayııı.

Mısır bitkisi örneklerinin BB, BTA ve TV değerlerine ait frekans dağlımları Șekil 2'de gösterilmiștir.

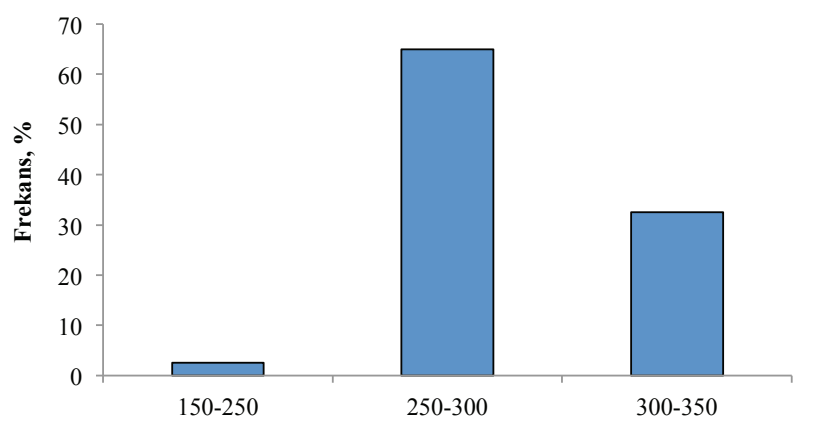

Șekil 2. Mısır bitki örneklerinin bitki boyu değerlerinin dağıııı ( $\mathrm{n}=40$ )

Figure 2. Distribution of plant height values of maize plant samples $(n=40)$

Șekil 2'de görüldüğü gibi; mısır bitkisinin BB değerlerinin \%2.5'i $150 \mathrm{~cm}$ ile $250 \mathrm{~cm}$; \%65'i $250 \mathrm{~cm}$ ile $300 \mathrm{~cm}$; $\% 32.5^{\prime} \mathrm{i}$ ise $300 \mathrm{~cm}$ ile $350 \mathrm{~cm}$ arasında değișmektedir. Ergül (2008) tarafından, silajık mısır çeșitlerinin önemli tarımsal ve kalite özelliklerinin belirlendiği bir çalıșmada; mısır çeșitlerinde bitki boylarının $298.0 \mathrm{~cm}$ ile $341.0 \mathrm{~cm}$ arasında değiștiği, ortalama bitki boyunun ise $322.2 \mathrm{~cm}$ olduğu belirtilmiștir. Yapılan araștırmaların birçoğunda bitki boyunun, genotiplere ve çevre șartlarına bağı olarak değiștiği bildirilmektedir (Whitman vd., 1985; Öktem ve Toprak, 2013).

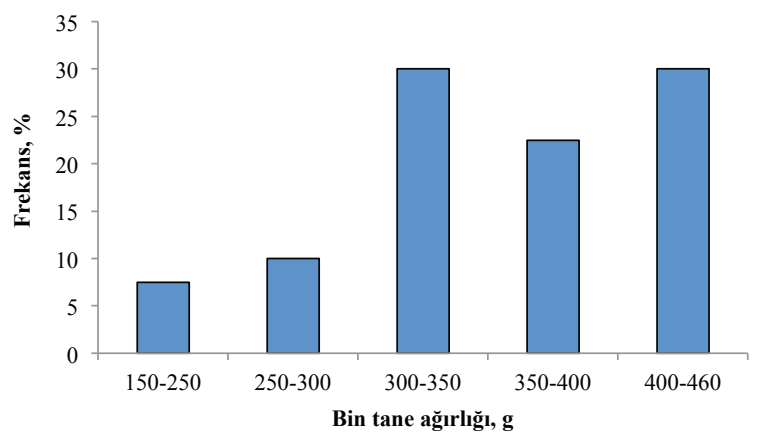

Șekil 3. Mısır bitki örneklerinin bin tane ağılığı değerlerinin dağılımı $(\mathrm{n}=40)$

Figure 3. Distribution of thousand seed weight values of maize plant samples $(n=40)$
Mısır bitkisinin BTA değerleri; \%7.5'i $150 \mathrm{~g}$ ile $250 \mathrm{~g}, \% 10^{\prime \prime u} 250 \mathrm{~g}$ ile $300 \mathrm{~g}, \% 30$ u $300 \mathrm{~g}$ ile $350 \mathrm{~g}, \% 22.5^{\prime} \mathrm{i} 350 \mathrm{~g}$ ile $400 \mathrm{~g}, \% 30 \mathrm{u}$ ise 400 $\mathrm{g}$ ile $460 \mathrm{~g}$ arasında olduğu saptanmıștır (Șekil 3). Mısır bitkisinin bin tane ağırlığı, çeșit ve çevre șartlarından önemli ölçüde etkilenmektedir. Ișık, su, bitki besin maddelerinin elverișli olduğu ortamlarda; bin tane ağırlık, çeșitin genetik kapasitesi ile sınırlı olarak artmakta ve en yüksek ağırlığa erișmektedir (Watson, 1987). Öner vd. (2012) tarafından, farklı lokasyonlarda yetiștirilen atdiși mısır çeșit ve hatlarının agronomik özellikler yönünden karșılaștırılan bir çalıșmada, Samsun lokasyonunda; en yüksek bin tane ağırlık değeri $379.3 \mathrm{~g}$ olarak saptanmıștır.

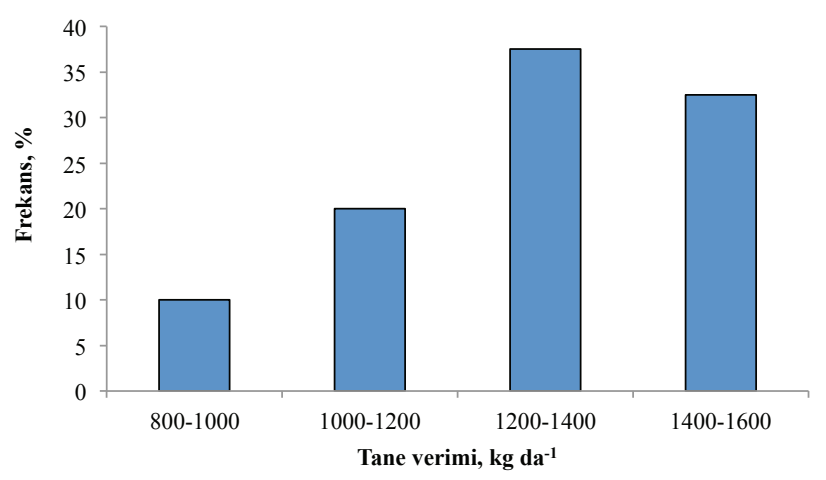

Șekil 4. Mısır bitki örneklerinin tane verim değerlerinin dağılımı (n=40)

Figure 4. Distribution of grain yield values of maize plant samples $(n=40$ )

Șekil 4'ten görüldüğü gibi; mısır bitkisinin TV değerlerinin \%10'u 800-1000 kg da' ; \%20'si 1000$1200 \mathrm{~kg}$ da-1; \%37.5'i 1200-1400 kg da' ; \%32.5'i ise $1400-1600 \mathrm{~kg} \mathrm{da}{ }^{-1}$ arasında saptanmıștır. Öktem (1993), Cukurova koșullarında ikinci ürün mısırda 14 farklı çeșit ile yaptığı bir çalıșmada; tane veriminin $827 \mathrm{~kg} \mathrm{da}^{-1}$ ile $1456 \mathrm{~kg} \mathrm{da}^{-1}$ arasında değiștiğini bildirmiștir. Öz ve Kapar (2003) tarafından, Samsun koșullarına uygun tanelik hibrit mısır genotipleri geliștirmek amacı ile yapılan bir çalıșmada; tane verimin $916 \mathrm{~kg} \mathrm{da}^{-1}$ ile $1349 \mathrm{~kg}$ $\mathrm{da}^{-1}$ arasında değiștiği tespit edilmiștir. Bitkide tane verim farklılıkları çeșitlerin genetik özellikleri, bakım ișlemleri ve toprak özelliklerinden kaynaklanabilir (Pamukçu vd., 2011 ; Özata vd., 2013). 
Çizelge 2. Mısır bitkisinin bazı agronomik özellikleri ile toprağın kimyasal ve fiziksel özelliklerine ilișkin korelasyon matrisi (n=40) Table 2. Correlation matrix for some agronomic properties of maize plant and chemical and physical properties of soil (n=40)

\begin{tabular}{|c|c|c|c|}
\hline Özellikler & $\mathrm{BB}, \mathrm{cm}$ & BTA, $g$ & $\mathrm{TV}, \mathrm{kg} \mathrm{da}^{-1}$ \\
\hline $\mathrm{BB}, \mathrm{cm}$ & 1 & & \\
\hline BTA, $g$ & -0.137 & 1 & \\
\hline $\mathrm{TV}, \mathrm{kg} \mathrm{da^{-1 }}$ & -0.053 & $0.542 * *$ & 1 \\
\hline Kil, \% & -0.235 & 0.085 & 0.006 \\
\hline Silt, $\%$ & 0.123 & -0.225 & -0.197 \\
\hline Kum, \% & 0.147 & 0.055 & 0.112 \\
\hline Db, $g \mathrm{~cm}-3$ & 0.207 & 0.032 & -0.116 \\
\hline TK, \% & -0.332 & 0.344 & 0.212 \\
\hline SN, \% & -0.322 & 0.361 & 0.287 \\
\hline BYS, \% & -0.276 & 0.247 & 0.051 \\
\hline $\mathrm{pH},(1: 1)$ & 0.020 & 0.255 & 0.117 \\
\hline $\mathrm{EC}, \mathrm{dS} \mathrm{m}-1(1: 1)$ & -0.112 & 0.431 * & $0.384^{*}$ \\
\hline $\mathrm{CaCO} 3, \%$ & 0.068 & -0.029 & 0.236 \\
\hline OM, \% & -0.135 & $0.378 *$ & $0.518 * *$ \\
\hline N, \% & -0.236 & $0.637 * *$ & $0.655^{* *}$ \\
\hline P. ppm & -0.051 & 0.024 & $0.377^{*}$ \\
\hline $\mathrm{K}, \mathrm{cmol} \mathrm{kg}^{-1}$ & -0.198 & 0.233 & $0.421 *$ \\
\hline $\begin{array}{c}\mathrm{Ca}+\mathrm{Mg}, \mathrm{cmol} \\
\mathrm{kg}^{-1}\end{array}$ & -0.148 & 0.284 & 0.192 \\
\hline $\mathrm{Na}, \mathrm{cmol} \mathrm{kg}^{-1}$ & 0.095 & -0.006 & $0.403 *$ \\
\hline $\mathrm{KDK}, \mathrm{cmol}^{\mathrm{kg}}{ }^{-1}$ & -0.146 & 0.285 & 0.221 \\
\hline Fe, ppm & -0.125 & -0.152 & -0.104 \\
\hline Mn, ppm & -0.010 & -0.231 & -0.168 \\
\hline Cu, ppm & -0.194 & $0.403^{*}$ & $0.556 * *$ \\
\hline Zn, ppm & -0.074 & 0.220 & $0.409 *$ \\
\hline
\end{tabular}

** $\mathrm{p} \leq 0.01$ hata düzeyinde çok önemli, * $\mathrm{p} \leq 0.05$ hata düzeyinde önemli

\section{Mısır bitkisinin bazı verim parametreleri ile toprağın bazı fiziksel ve kimyasal özellikleri arasındaki ilișkiler}

Mısır bitkisinin verim parametreleri ile toprağın bazı fiziksel ve kimyasal parametrelerine ait korelasyon katsayıları (r) Tablo 2'de verilmiștir. BTA ile TV arasında çok önemli pozitif ilișki $\left(0.542^{* *}\right)$ saptanmıștır. Mısır bitkisinin TV verim değeri; toprakların $\mathrm{OM}$, Cu ve $\mathrm{N}$ değerleri ile çok önemli, EC, P, K, Na ve Zn değerleri ile ise önemli pozitif ilișkiler göstermiștir. Mısır bitkisinin agronomik özellikleriyle, toprakların diğer fiziksel ve kimyasal parametreleri arasında ise istatistiksel açıdan önemli bir ilișki tespit edilmemiștir. Angelov (1994), tane verimi ile olgunlașma süresi, bitki boyu, bitkide yaprak sayısı ve ilk koçan yüksekliği arasında önemli ve yüksek korelasyon ilișkisinin olduğunu bildirmiștir. Alp (2010) tarafından yapılan bir çalıșmada, Zn toprakta yeterince bulunduğu zaman; özellikle bitki büyüme hormonlarının tam olarak oluștuğu, tohum veriminin artığı, mısırda gövde ve tane olgunluğu sağladığı gösterilmiștir. Ayrıca, mısır bitkisinin bin tane ağırlığı; toprakların OM ve N içeriği ile çok önemli, EC değeriyle ise önemli pozitif ilișki verdiği saptanmıștır.

\section{Verim parametreleri ile toprakların bazı fiziksel ve kimyasal özellikleri arasındaki regresyon modeller}

Mısır bitki boyu ile toprakların bazı fiziksel ve kimyasal özellikleri arasındaki regresyon modeller Çizelge 3'te verilmiștir. Regresyon modellerinin olușturulmasında buğday bitki boyu ile toprakların bazı fiziksel ve kimyasal özelliklerine ilișkin korelasyon analiz sonuçları (Çizelge 2) dikkate alınmıștır.

Çizelge 3. Mısırda bitki boyu ile toprakların bazı fiziksel ve kimyasal özellikleri arasındaki regresyon modelleri $(n=40)$ Table 3. Regression models between maize plant height and some physical and chemical properties of soils ( $n=40$ )

\begin{tabular}{|c|c|c|c|c|}
\hline \multicolumn{2}{|r|}{ Modeller } & \multirow{2}{*}{$\frac{R}{0.395}$} & \multirow{2}{*}{$\frac{F}{0.53}$} & \multirow{2}{*}{$\frac{P}{0.803}$} \\
\hline 1. & $\begin{array}{l}\mathrm{BB}=259+63.6 \mathrm{HA}-0.179 \mathrm{Kil}-1.06(\mathrm{HA} \times \mathrm{SN})+14 \mathrm{EC}-3.0 \mathrm{OM} \\
+0.69 \mathrm{CaCO}_{3}-28 \sqrt{E C}\end{array}$ & & & \\
\hline 2. & $\begin{array}{l}\mathrm{BB}=304-7.60\left(\mathrm{CaCO}_{3}\right)^{2}-73.7(\mathrm{EC})^{2}+3.63(\mathrm{OM})^{2}+65.5 \mathrm{HA} \\
-1.59 \mathrm{TK}-412+0.737(\mathrm{Ca}+\mathrm{Mg})+58.3 \mathrm{CaCO}_{3}\end{array}$ & 0.514 & 0.85 & 0.570 \\
\hline 3. & $\begin{array}{l}\mathrm{BB}=318-9.07\left(\mathrm{CaCO}_{3}\right)^{2}-74.6(\mathrm{EC})^{2}+8.8(\mathrm{OM})^{2}+84.4 \mathrm{HA} \\
-1.96 \mathrm{TK}-414+0.984(\mathrm{Ca}+\mathrm{Mg})+70.0 \mathrm{CaCO}_{3}-26.8 \mathrm{OM} \\
4.30 \sqrt{\text { Kum }}\end{array}$ & 0.543 & 0.71 & 0.703 \\
\hline
\end{tabular}

BB: Misır bitki boyu, cm; EC: Elektriksel iletkenlik, dS ml; OM: Organik madde, \%; N: Azot, \%; CaCO $:$ Kirec, \%; Ca+Mg: Kalsiyum+Magnezyum, cmol kg-'; HA: Hacim ağırlığı, $\mathrm{g} \mathrm{cm-}^{-}$; SN: Solma noktası, \%; TK: Tarla kapasitesi, \%. 
Çizelge 4. Mısırda bin tane ağırlığı ile toprakların bazı fiziksel ve kimyasal özellikleri arasındaki regresyon modelleri (n=40)

Table 4. Regression models between thousand seed weight and some physical and chemical properties of soils in maize (n=40)

\begin{tabular}{|c|c|c|c|c|}
\hline & Modeller & $\mathrm{R}$ & $F$ & $p$ \\
\hline 1. & $\begin{array}{l}B T A=-178+208 E C-7.66 \mathrm{CaCO}+24.3 \mathrm{OM}+10.6 \mathrm{Kil}+292 \mathrm{HA} \\
-8.05 \text { (HAxKil) }\end{array}$ & 0.594 & 1.94 & 0.126 \\
\hline 2. & $\begin{array}{l}\mathrm{BTA}=382-34.3 \mathrm{OM}+1713 \mathrm{~N}+1.76 \mathrm{KDK}+9.83(\mathrm{HA} \times \mathrm{Kum}) \\
-2.85 \mathrm{SN}-13.4 \mathrm{Kum}-129(\mathrm{HA})^{2}\end{array}$ & 0.779 & 4.41 & 0.004 \\
\hline 3. & 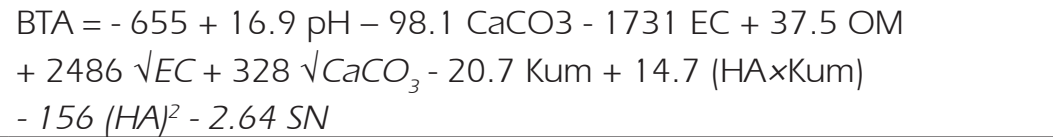 & 0.819 & 3.45 & 0.012 \\
\hline
\end{tabular}

BTA: Mısır bin tane ağırlığı, g; pH: Toprak reaksiyonu; EC: Elektriksel iletkenlik, dS m-1; OM: Organik madde, \%; N: Azot, \%; CaCO3: Kirec, \%; HA: Hacim ağırlığı, g cm-3; SN: Solma noktası, \%.

Çizelge 3'ten de görüldüğü gibi, modellerin; regresyon katsayıları 0.395 ile 0.543 , F değerleri 0.53 ile 0.85 , p değerleri ise 0.570 ile 0.803 arasında değișmektedir. F değeri etkileșim ve ana etkenlerin anlamlı olup olmadığını belirlemek için yapılmakta ve $p$ değeri düștükçe F'nin değeri büyümektedir. EC, Ca+Mg, OM, HA, N, TK ve kum parametreleri ile olușturulan 3 numaralı modelde belirleme katsayısı en yüksek ( $R=0.543)$; $\mathrm{CaCO}_{3}, \mathrm{HA}$, SN ve OM içeren 1 numaralı modelde ise en düșük belirleme katsayısı (R= 0.395) saptanmıștır. p değerlerine göre ise regresyon modelleri istatistiksel olarak anlamlı değildir. Yapılan araștırmalar, regresyon modellerinin toprak özelliklerinin karesi, karekökü ve çarpımını kapsayan polinomlarla ifadesinin, regresyon katsayısını, dolayısıyla tahminin önem düzeyini yükselttiğini göstermektedir (Kosheleva vd., 2002; Gülser vd., 2007). Ekberli ve Dengiz (2017) yaptıkları bir araștırmada; farklı topoğrafik pozisyonlar üzerinde olușmuș toprakların çeșitli horizonlarının bazı fiziksel ve kimyasal özellikleri arasında olușturdukları regresyon modellerinde regresyon katsayılarının 0.615-0.998 arasında değiștiğini ve organik madde, kil, Ca+Mg özelliklerinin KDK'nın artıșına etki yaptığını bildirmișlerdir.
Mısır bin tane ağırlığı ile toprakların özelliklerine ilișkin korelasyon analiz sonuçları (Çizelge 2) göz önüne alınarak olușturulan regresyon modeller Çizelge 4'te verilmiștir. Çizelge 4'ten görüldüğü gibi, modellerin; regresyon katsayıları 0.594 ile 0.819 , F değerleri 1.94 ile 3.45, $\mathrm{P}$ değerleri ise 0.004 ile 0.126 arasında değișmektedir. $\mathrm{pH}, \mathrm{EC}$, CaCO3, OM, HA, kum, SN parametrelerini ve bazı parametre değerlerinin karesini, çarpımını, kare kökünü de kapsayan 3 numaralı modelde çoklu belirleme katsayısı en yüksek ( $R=0.819)$, $p$ değeri ise istatistiksel anlamlılık sınırı $(p<0.05)$ dâhilinde $(p=0.012)$; $E C, \mathrm{CaCO}_{3}, \mathrm{HA}$ ve kil içeren 1 numaralı modelde ise en düșük belirleme katsayısı ( $R=0.594)$ saptanmıș, $p$ değeri ise ( $P$ > $0.1)$ istatistiksel olarak anlamlı bulunmamaktadır. Karadavut vd (2010), silajlık ve danelik mısırlarda kuru madde birikimini tahmin etmek için bazı matematiksel büyüme modelleri kullanarak modellerin regresyon katsayılarını sırasıyla $\left(R^{2}\right)$ 0.93; 0.95 olarak hesaplamıștır.

Mısır tane verimi ile toprakların bazı fiziksel ve kimyasal özellikleri arasındaki regresyon modellerinden (Çizelge 5) görüldüğü gibi, modellerin regresyon katsayıları 0.752 ile 0.894 ;

Çizelge 5. Mııırda tane verimi ile toprakların bazı fiziksel ve kimyasal özellikleri arasındaki regresyon modelleri $(\mathrm{n}=40)$

Table 5. Regression models between grain yield and some physical and chemical properties of soils in maize ( $n=40)$

\begin{tabular}{|c|c|c|c|c|}
\hline & Modeller & $R$ & $\mathrm{~F}$ & $p$ \\
\hline 1. & $\begin{array}{l}T V=3095+7.3 p H-237 E C+53.9 O M-1582 H A-2.82 \text { Silt } \\
-126 S N+103(H A x S N)+41.9 \mathrm{CU}\end{array}$ & 0.594 & 1.94 & 0.126 \\
\hline 2. & $\begin{array}{l}\text { TV }=743+79 \mathrm{EC}-102 \mathrm{OM}+3.68 \mathrm{Ca}+\mathrm{Mg}+67.6 \mathrm{Na}+2855 \\
+74.5 \mathrm{Zn}-6.51 \mathrm{SN}-378 \mathrm{HA}-0.46 \text { Silt }\end{array}$ & 0.779 & 4.41 & 0.004 \\
\hline 3. & $\begin{array}{l}\mathrm{TV}=2705-97.9 \mathrm{OM}+3762 \mathrm{~N}+6.22 \mathrm{P}-270 \mathrm{~K}+2.65 \mathrm{Ca}+\mathrm{Mg} \\
+64.8 \mathrm{Na}+18.0 \mathrm{Zn}-91.8 \mathrm{SN}-1472 \mathrm{HA}-2.08 \mathrm{Silt}+76.3(\mathrm{HA} \times \mathrm{SN})\end{array}$ & 0.819 & 3.45 & 0.012 \\
\hline
\end{tabular}

TV: Misır tane verimi, kg da-1; pH: Toprak reaksiyonu; EC: Elektriksel iletkenlik, dS m-1; OM: Organik madde, \%; N: Azot, \%; P: Fosfor, ppm; K: Potasyum, cmol kg-1; Zn: Çinko, ppm; Na: Sodyum, cmol kg-1; Ca+Mg: Kalsiyum+Magnezyum, cmol kg-1; HA: Hacim ağırlığı, g cm-3; SN: Solma noktası, \%. 
F değerleri 3.10 ile 5.83; p değerleri ise 0.001 ile 0.020 arasında olup, $p<0.05$ ve $p<0.01$ düzeyinde istatistiksel anlamlılık göstermiștir. En yüksek belirleme katsayısı 3 numaralı modelde ( $R=0.894)$, en düșük belirleme katsayısı ( $R$ $=0.752$ ) ise 1 numaralı modelde saptanmıș olup, modellerin regresyon katsayıları yüksek düzeyde bulunmuștur. Budka vd. (2015), tarımsal uygulamada fungal hastalık enfeksiyonundan kaynaklanan verim kayıplarını tahmin etmek için regresyon denklemleri kullanmıșlardır. Araștırmacılar regresyon katsayılarının $\left(R^{2}\right) \quad 0.077$ ile 0.343 arasında değiștiğini, verim azalmasının
Çizelge 6. Mısır bitki boyu, mısır bin tane ağırlığı ve mısır tane verimine ait regresyon modellerine ait bazı istatistiksel parametreler $(n=28))$

Table 6. Some statistical parameters of regression models of maize plant height, maize thousand seed weight and maize grain yield ( $n=28$ )

\begin{tabular}{ccccc}
\hline Modeller (No) & R & HKOK & $d$ & ME \\
\hline BB & 0.543 & 13.799 & 0.985 & 0.376 \\
BTA & 0.819 & 28.952 & 0.995 & 0.644 \\
TV & 0.894 & 122.719 & 0.952 & -0.112
\end{tabular}

BB: Mısır bitki boyu; BTA: Mısır bin tane ağırlığı; TV: Mısır tane verimi; R: Regresyon katsayısı; HKOK: Hata kareler ortalamasının karekökü; d: Uygunluk indeksi; ME: Modelin etkinliği
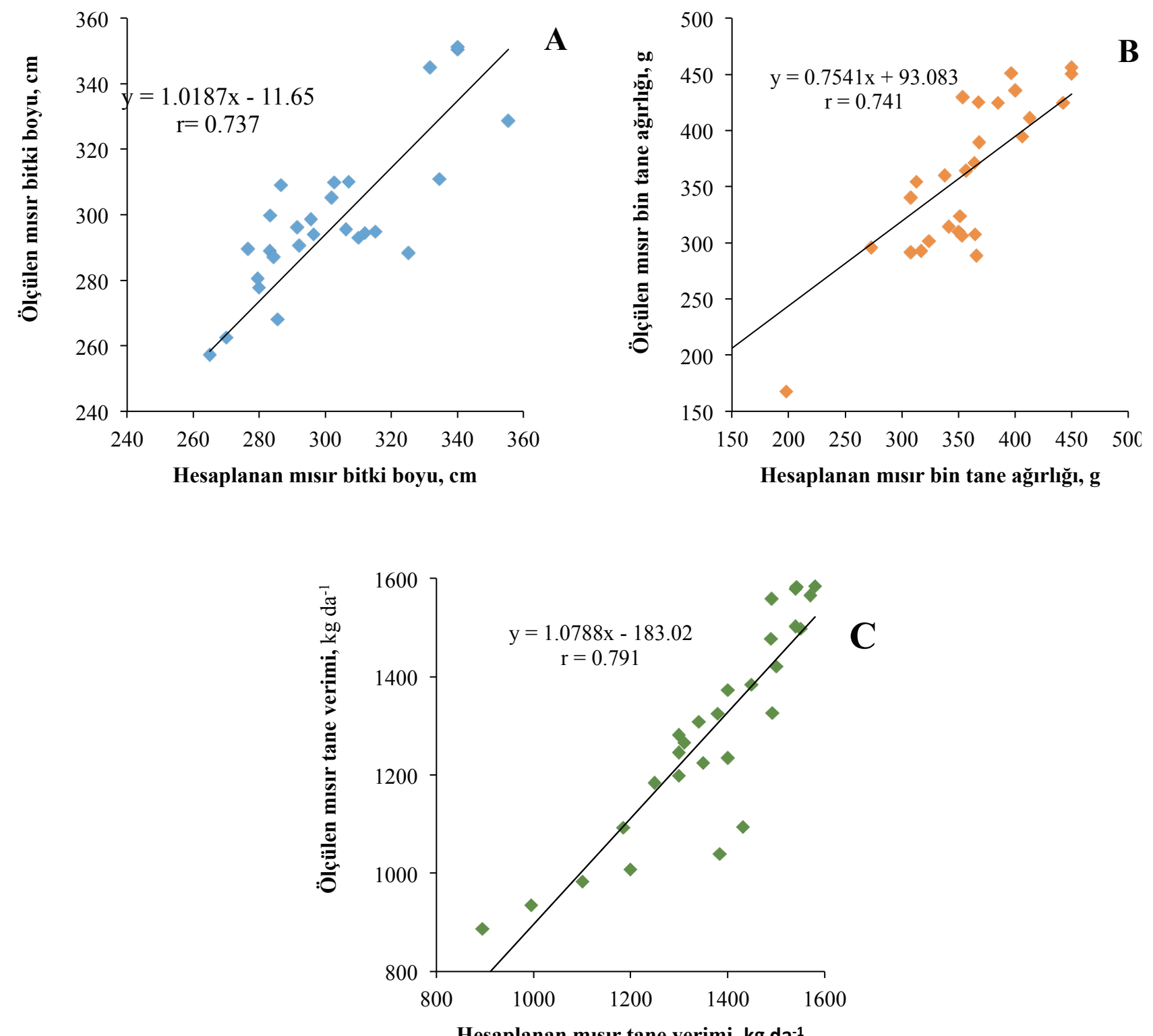

Șekil 5. Mısır bitki boyu (A), bin tane ağılığı (B), tane verimi (C) ile toprakların fiziksel ve kimyasal özellikleri arasındaki regresyon modellerine göre hesaplanan ve ölçülen değerler

Figure 5. Maize plant height (A), thousand seed weight (B), grain yield (C) and physical and chemical properties of the soils calculated and regression models 
tahmininde bölgenin toprak ve iklim koșullarının ve yaprak tipinin dikkate alınması gerektiğini bildirmișlerdir. Malone vd. (2007), tarafından, mısır ve soyada tane verimini tahmin etmek için olușturdukları regresyon denklemlerinin belirleme katsayılarını sırasıyla $\left(R^{2}\right) \quad 0.85 ; 0.87$ olduğu saptanmıștır.

\section{Verim parametreleri ile toprak özellikleri arasında olușturulan regresyon modellerin geçerlilikleri}

Deneysel verilere göre elde edilen regresyon modellerin geçerliliklerinin belirlenmesinde, modellerin olușturulmasında kullanılan değerler dıșındaki veya veri bankasındaki değerlerden kullanılması gerekmektedir (Wang vd., 2016). Mısır BB, BTA ve TV ile toprakların bazı fiziksel ve kimyasal özellikleri arasındaki regresyon modellerinin geçerliliğinin belirlenmesine ait istatistiksel parametreler Çizelge 6'da verilmiștir.

Çizelge 6'dan görüldüğü gibi, regresyon modellere ait istatistiksel göstergeler genel olarak, geçerlilik sınırları dâhilinde değișmektedir. Mısır tane verimine ait regresyon modelinde HKOK değerinin nispeten büyük olmasının nedeni, tane verimine ait deneysel verilerin homojen olmaması, dolayısıyla geniș aralıkta değișmesinden kaynaklanmaktadır. Karadavut vd. (2010), üç farklı modeli kullanarak mısır çeșitlerinde kuru madde birikimini tahmin ettikleri bir çalıșmada, ME değerlerini 96.78; 94.20; 84.35; 89.98; 82.91; 95.14 olarak belirlenmiștir. Banimahd ve Zand-Parsa (2013) tarafından yapılan bir çalıșmada olușturulan farklı modellerde HKOK değerleri sırasıyla 65.7; 140.3 ve 190.7 olarak belirlenmiștir.

Mısır bitki boyu, bin tane ağırlığı, tane veriminin üçüncü modele göre hesaplanan ve ölçülen değerlerin karșılaștırılması Șekil 5'te verilmiștir. Mısır BB, BTA, TV ile toprakların fiziksel ve kimyasal özellikleri arasındaki regresyon modellere göre hesaplanan ve ölçülen değerler arasındaki doğrusal regresyonların $r$ değerleri sırasıyla 0.737, 0.741 ve 0.791 olup, 0.01 düzeyinde istatistiksel olarak anlamlı bulunmuștur.

\section{SONUÇLAR}

Farklı tarım bitkilerinin yetiștirildiği toprakların toprak özellikleriyle verim parametreleri arasındaki deneysel ilișkilerin belirlenmesi, verimin değerlendirilmesi ve tahmin edilmesinde önemlidir. Deneysel ilișkiler, verim ile toprak özellikleri arasındaki karșııklı etkileșmeyi nicel olarak değerlendirmektedir. Çarșamba Ovası́nda geleneksel toprak ișleme yöntemleriyle ana ürün olarak mısır bitkisi yetiștirilen tarım topraklarının bazı fiziksel ve kimyasal özellikleri ile bitki verim parametreleri arasında regresyon modeller olușturulmuștur. Regresyon modellerinin olușturulmasında, genel olarak aralarındaki ilișkiler önemli ve çok önemli düzeyde olan parametreler esas alınmıștır. BB, BTAve TV bitkiverim unsurlarıyla, toprak parametrelerinin karesini, çarpımını ve karekökünü içeren üç numaralı modellerin performansı daha yüksek bulunmuștur. Ölçülen ve regresyon modellerinden kullanılarak hesaplanan verim değerlerinin karșılaștııılması; istatistiksel parametrelerin değerlendirilmesi elde edilen regresyon modellerin araștırma bölgesinin mısır yetiștirilen topraklarında verim parametrelerinin tahmini için uygulanabilirliğini göstermektedir. Araștırma alanında çiftçiler tarafından düzenli tarımsal ișlemlerin (gübreleme, sulama vb.) yapılmaması, iklim koșullarının değișimi gibi faktörler, fiziksel ve kimyasal özelliklerin olumsuz yönde etkilenmesine, toprak özelliklerinin kısa mesafelerde veya zaman aralıklarında değișmesine neden olmakta, dolayısıyla verim parametreleri ile fiziksel ve kimyasal özellikler arasındaki regresyon modellerin performansına da etki yapmaktadır. Regresyon modellerin olușturulmasının ve uygulanmasının kolaylığını göz önüne alarak, yerel ve bölgesel düzeyde çeșitli bitkiler için farklı regresyon modellerin yapılabilmesi için, toprak özelliklerine ve bitkilerin verim unsurlarına ait veri bankasının olușturulması gerekmektedir. Ayrıca regresyon modellerin geçerliliğinin belirlenmesinde modellerin olușturulmasında kullanılmayan verilerden faydalanılması gerekmektedir. Genel olarak, bitki verimi ile toprak özellikleri arasındaki modellerin olușturulmasında, parametrelerin daha fazla olması (>10-15) modelin uygulanabilirliğini zorlaștırdığından, benzer etkiye sahip parametrelerin birleștirerek daha az sayıda verilerden kullanılması uygun gözükmektedir.

\section{KAYNAKLAR}

Alp A (2010). Farklı yaprak gübresi uygulamalarının bazı ekmeklik ve makarnalık buğday çeșit ve hatlarının verim ve verim öğeleri üzerine etkileri. Mustafa Kemal Üniversitesi Ziraat Fakültesi Dergisi, 15(2): 1-16.

Alexandrov VA, Hoogenboom G (2000). The impact of climate variability and change on crop yield in Bulgaria. Agricultural and Forest Meteorology, 104(4): 315-327. 
Angelov K (1994). Correlations between grain yield and certain plant and ear chracteristics in maize hybrids. Field Crop Abstracts, 47: 133.

Anonim (1984). Samsun İli Verimlilik Envanteri ve Gübre İhtiyacı Raporu. Yayın No:23, Genel Yayın No:760, Ankara.

Anonim (2013). Tohumluk Tescil ve Sertifikasyon Merkez Müdürlüğü. https://www.tarimorman.gov.tr/BUGEM/TTSM/ Belgeler/Tescil/Teknik\%20Talimatlar/S\%C4\%B 1 cak\%20 \%C4\%B0klim\%20Tah\%C4\%B1 llar\%C4\%B1/MISIR_TEKNIK_ TALIMATI.pdf (Erișim tarihi: 13.09.2019).

Anonim (2016). Türkiye İstatistik Kurumu. https:// biruni.tuik.gov.tr/medas $/ \mathrm{kn}=92$ \&locale $=\mathrm{tr}$ (Access date: 17.04.2017)

Anonymous (1954). United States Salinity Laboratory Staff. Diagnosis and Improvement of Saline and Alkaline Soils. (Ed L.A. Richards). USDA Agriculture Handbook No: 60, U.S. Goverment Printing Office, Washington.

Aydoğan S, Soylu S (2017). Ekmeklik buğday çeșitlerinin verim ve verim öğeleri ile bazı kalite özelliklerinin belirlenmesi. Tarla Bitkileri Merkez Araștırma Enstitüsü Dergisi, 26(1): 2430.

Banimahd SA, Zand-Parsa SH (2013). Simulation of evaporation, coupled liquid water, water vapor and heat transport through the soil medium. Agricultural Water Management, 130: 168-177.

Bayraklı F (1987). Toprak ve Bitki Analizleri. Ondokuz Mayıs Üniversitesi Yayınları, No:17, Samsun.

Bayraklı F, Ekberli İ, Gülser C (1999). Azerbaycan Mil ovası topraklarının verimlilik düzeylerinin deneysel ve matematiksel olarak değerlendirilmesi. Ondokuz Mayıs Üniversitesi Ziraat Fakültesi Dergisi, 14(2): 138-153.

Black CA (1965). Methods of Soil Analysis Part I-Physical and Mineralogical Methods. Soil Science Society of America, No: 9, USA.

Bouma J (1989). Using soil surve data for quantitative land evaluation. Advances Soil Science, 9: 177-213.

Bouma J, van Lanen HAJ (1987). Transfer functions and threshold values: from soil characteristics to land qualities. In Proceedings of the International Workshop on Quantified Land Evaluation Procedures, Washington, DC, USA, pp. 106110.

Budka A, Lacka A, Gaj R, Jajor E, Korbas K (2015). Predicting winter wheat yields by comparing regression equations. Crop Protection, 78: 84-91.

Campbell GS, Shiozawa S (1992). Prediction of hydraulic properties of soils using particle-size distribution and bulk density data. In: Van Genuchten MT, Leij FJ and Lund $\sqcup$. (Eds.). Proceedings of International Workshop on Indirect Methods for Estimating the Hydraulic Properties of Unsaturated Soils. University of California, Riverside, pp. 317 328.

Çolakoğlu H (1985). Gübre ve Gübreleme. Ege Üniversitesi Ziraat Fakültesi Yayınları, Teksir no: 1 7-1, Bornova, İzmir.

Demiralay i (1993). Toprak Fiziksel Analizleri. Atatürk Üniversitesi Ziraat Fakültesi Yayınları No: 143, Erzurum.
Dengiz O, Ekberli i (2017). Bazı vertisol alt grup topraklarının fizikokimyasal ve ısısal özelliklerinin incelenmesi. Akademik Ziraat Dergisi, 6(1): 45-52.

Dorsey JW, Hardy LC (2018). Sustainability factors in dynamical systems modeling: Simulating the non-linear aspects of multiple equilibria. Ecological Modelling, 368: 6977.

Ekberli i, Dengiz O (2016). Bazı inceptisol ve entisol alt grup topraklarının fizikokimyasal özellikleriyle ısısal yayınım katsayısı arasındaki regresyon ilișkilerin belirlenmesi. Toprak Su Dergisi, 5(2): 1-10.

Ekberli I, Dengiz O (2017). Bazalt ana materyali ve farklı topografik pozisyon üzerinde olușmuș toprakların bazı topografik özellikler ve fiziksel-kimyasal özellikleri arasındaki doğrusal regresyon modellerinin belirlenmesi. Toprak Su Dergisi, 6(1): 15-27.

Ekberli i, Kerimova E (2005). Azerbaycan'ın Șirvan bölgesinde sulanan killi bir toprağın bazı fiziksel-kimyasal parametrelerinin değișimi. Ondokuz Mayıs Üniversitesi Ziraat Fakültesi Dergisi, 20(3): 54-59.

Ergül Y (2008). Silajlık mısır çeșitlerinin önemli tarımsal ve kalite özelliklerinin belirlenmesi. Yüksek Lisans Tezi, Selçuk Üniversitesi Fen Bilimleri Enstitüsü Tarla Bitkileri Anabilim Dalı, 60, Konya.

Gençtan T, Sağlam N (1987). Ekim zamanı ve ekim sıklığının üç ekmeklik buğday çeșidinde verim ve verim unsurlarına etkisi. Türkiye Tahıl Sempozyumu, Bildiriler Kitabı, 6-9 Ekim, Bursa, s. 171-183.

Guber AK, Pachepsky YA, van Genuchten MT, Simunek J, Jacques D, Nemes A, Nicholson TJ, Cady RE (2009). Multimodel simulation of water flow in a field soil using pedotransfer functions. Vadose Zone Journal, 8(1): 1-10.

Gülser C (2004). Tarla kapasitesi ve devamlı solma noktası değerlerinin toprakların fiziksel ve kimyasal özellikleriyle ilișkili pedotransfer eșitliklerle belirlenmesi. Ondokuz Mayıs Üniversitesi Ziraat Fakültesi Dergisi, 19(3): 19-23.

Gülser C, Candemir F, İç S, Demir Z (2007). Pedotransfer modellerle ince bünyeli topraklarda doygun hidrolik iletkenliğin tahmini. V. Ulusal Hidroloji Kongresi, Bildiriler Kitabı, 5-7 Eylül, Ankara, s. 563-569.

Gülser C, Ekberli I, Candemir F (2016). Spatial variability of soil physical properties in a cultivated field. Eurasian Journal of Soil Science, 5(3): 192-200.

Huang F, Zhan W, Ju W, Wang Z (2014). Improved reconstruction of soil thermal field using two-depth measurements of soil temperature. Journal of Hydrology, 519: 711-719.

Jackson ML (1962). Soil Chemical Analysis. Prentice Hall. Inc. Englewood Cliffs, New Jersey, USA, pp. 219-221.

Kacar B (1994). Bitki ve Toprağın Kimyasal Analizleri III, Toprak Analizleri. Ankara Üniversitesi Ziraat Fakültesi, Eğitim Araștırma ve Geliștirme Vakfı Yayınları, No: 3, Ankara.

Karadavut U, Genç A, Tozluca A, Palta C (2010). Silajlık ve danelik mısırlarda kuru madde birikiminin bazı matematiksel büyüme modelleri ile analizi. Journal of Agricultural Sciences, 16: 89-96. 
Kars, N., Ekberli, İ. (2019a). Buğday bitkisinin verim parametreleri ile bazı toprak özellikleri arasındaki pedotransfer modellerin uygulanabilirliği. Türkiye Tarımsal Araștırmalar Dergisi, 6(2): 153-164.

Kars N, Ekberli i (2019b). Çarșamba Ovasının buğday bitkisi altındaki topraklarının bazı fiziksel ve kimyasal özelliklerinin incelenmesi. Toprak Su Dergisi, 8(1): 18-28.

Krause, P., Boyle, D.P., Base, F. (2005). Comparison of different efficiency criteria for hydrological model assessment. Advances in Geosciences, 5: 89-97.

Korkmaz A, Bayraklı F, Cülser C, Ekberli IA (2000). Bafra ve Çarșamba Ovalarında mısır bitkisinin azotlu ve fosforlu gübre intiyacının belirlenmesinde matematiksel modellerin uygulanabirliği. Ondokuz Mayıs Üniversitesi Ziraat Fakültesi Dergisi, 15(1): 33-40.

Korkut KZ, Sağlam N, Bașer i (1993). Ekmeklik ve makarnalık buğdaylarda verimi etkileyen bazı özellikler üzerine araștırmalar. Trakya Üniversitesi Tekirdağ Ziraat Fakültesi Dergisi, 2(2): 111-118.

Kosheleva NE, Kasimov NS, Samonova OA (2002). Regression models fort he behavior of heavy metals in soils of the Smolensk-Moskow upland. Pocvovedeniye, 8: 954-966.

Kumar $P$, Sarangi A, Singh DK, Parihar SS, Sahoo RN (2015). Simulation of salt dynamics in the root zone and yield of wheat cropunder irrigated saline regimes using SWAP model. Agricultural Water Management, 148: 72-83.

Lindsay L, Norvell WA (1978). Development of a DTPA soil test for zinc, iron, manganese and copper. Soil Science Society of America Journal, 42(3): 421-428.

Malone RW., Ma L, Karlen DL, Meade T, Meek D, Heilman P, Kanwar RS, Hatfield JL (2007). Empirical analysis and prediction of nitrate loading and crop yield for corn-soybean rotations. Geoderma, 140: 223-234.

Olsen SR, Cole CV, Watanabe FS, Dean LA (1954). Estimation of available phosphorus in soil by extraction with sodium bicarbonate. U.S. Department of Agriculture, Circular No. 939.

Overman AR, Scholtz III RV (2002). Mathematical models of crop growth and yield. Marcel Dekker, Inc., New York, $325 \mathrm{p}$.

Öner F, Sezer I, Gülümser A (2012). Farklı lokasyonlarda yetiștirilen atdiși mısır (Zea mays L. indendata) çeșit ve hatlarının agronomik özellikler yönünden karșılaștırılması. Tekirdağ Ziraat Fakültesi Dergisi, 9(2): 1-6.

Öktem A (1993). Çukurova koșullarında II.ürün olarak denenen mısır çeșitlerinde tane verimi ve verime etkili bazı tarımsal özellikler ile bu özellikler arasındaki etkileșimlerin belirlenmesi Yüksek Lisans Tezi, Çukurova Üniversitesi Fen Bilimleri Enstitüsü Tarla Bitkileri Anabilim Dalı, 65, Adana.

Öktem A, Toprak A (2013). Çukurova koșullarında bazı atdiși mısır (Zea mays L. indentata) genotiplerinin verim ve morfolojik özelliklerinin belirlenmesi. Harran Üniversitesi Ziraat Fakültesi Dergisi, 17(4): 15-24.

Öz A, Kapar H (2003). Samsun koșullarında geliștirilen çeșit adayı mısırların verim öğelerinin belirlenmesi ve stabilite analizi. Tarım Bilimleri Dergisi, 9(4): 454-459.
Özata E, Geçit HH, Öz A, İkincikarakaya SÜ (2013). Atdiși hibrit mııı adaylarının ana ürün koșullarında performanslarının belirlenmesi. Iğdır Üniversitesi Fen Bilim Enstitüsü Dergisi, 3(1): 91-98.

Özdemir N, Ekberli I, Kop Durmuș ÖT (2018). Bazı toprak özellikleri ile kütle yoğunluğunun tahmini için pedotransfer modeller. Toprak Bilimi ve Bitki Besleme Dergisi, 6(1): 46-51.

Özdemir N, Gülser C, Ekberli İ, Kop ÖT (2014). Asit toprakta düzenleyici uygulamalarının bazı toprak özellikleri ve verime etkileri. Toprak Bilimi ve Bitki Besleme Dergisi, 2(1): 27-32.

Özgentürk G (2001). Çukurova Bölgesinde yetiștirilen at diși melez mısır çeșitlerinde tane verimi ile bazı tarımsal özellikler arasındaki ilișkilerin belirlenmesi. Yüksek Lisans Tezi, Çukurova Üniversitesi Fen Bilimleri Enstitüsü Tarla Bitkileri Anabilim Dalı, Adana.

Pachepsky YA, Rawls WJ (2004). Development of pedotransfer functions in soil hidrology. Development in Soil Science, 30: 497p.

Pamukçu M, Erdal G, Savur O, Toros A, Özata E (2011). Beyaz hibrit mısır aday çeșitlerinin Antalya ve Samsun koșullarında performanslarının değerlendirilmesi. Türkiye 9. Tarla Bitkileri Kongresi s: 513-516, Bursa.

Park DK, Hossain MA, Uddin MJ (1986). Correlation and path coenfficient analysis in open pollinated maize. Bangladesh-Journal of Agriculture, 11(1): 11-14.

Patil NG, Singh SK (2016). Pedotransfer functions for estimating soil hydraulic properties: A Review. Pedosphere, 26(4):417-430.

Richards LA (1954). Diagnosis and Improvement of Saline and Alkali Soils. United States Department of Agriculture, Handbook No: 60, pp. 105-106.

Sağlam MT (1997). Toprak ve Suyun Kimyasal Analiz Yöntemleri. Tekirdağ Üniversitesi Ziraat Fakültesi Yayınları, No: 189.

Sönmez F (2001). Azotun bazı mısır çeșitlerinde tane verimi ve verim komponentlerine etkisi. Gazi Osman Pașa Üniversitesi Ziraat Fakültesi Dergisi, 18(1): 107-212.

Taban S, Çıkılı Y, Kebeci F, Taban N, Sezer SM (2004). Tașköprü yöresinde sarımsak tarımı yapılan toprakların verimlilik durumu ve potansiyel beslenme problemlerinin ortaya konulması. Tarım Bilimleri Dergisi, 10(3): 297-304.

Thiery D, Amraoui N, Noyer ML (2018). Modelling flow and heat transfer through unsaturated chalk-Validation with experimental data from the ground surface to the aquifer. Journal of Hydrology, 556: 660-673.

Tosun O, Yurtman N (1973). Ekmeklik buğdaylarda (Triticum aestivum L. em Thell) verime etkili morfolojik ve fizyolojik özellikler. Ankara Üniversitesi Ziraat Fakültesi Yıllığı, 23: 418-434.

Turan, M., Dengiz, O., Turan Demirağ, i (2018). Samsun ilinin Newhall modeline göre toprak sıcaklık ve nem rejimlerinin belirlenmesi. Türkiye TarımsalAraștırmalar Dergisi, 5(2): 131-142.

Vereecken $\mathrm{H}$, Weynants M, Javaux M, Pachepsky $\mathrm{Y}$, Schaap MG, Van Genuchten, MT (2010). Using pedotransfer functions to estimate the van Genuchten-Mualem soil hydraulic properties: A review. Vadose Zone Journal, 9(4): 795-820. 
Wang L, Lia X, Chen Y, Yang K, Chen D, Zhou J, Liu W, Qi J, Huang J (2016). Validation of the global land data assimilation system based onmeasurements of soil temperature profiles. Agricultural and Forest Meteorology, 218-219: 288-297.

Watson AS (1987). Structure and Composition. Corn: Chemistry and Technology. Association of Cereal Chemistry. Inc. Saint Paul. pp. 53-82, Minnesota.

Whitman CE, Haffield JL, Reginato RJ (1985). Effect of slope position on the microclimate, growth, and yield of barley. Agronomy Journal, 77(5): 663-669.
Willmott CJ, Matsuura K (2005). Advantages of the mean absolute error (MAE) over the root mean square error (RMSE) in assessing average model performance. Climate Research, 30(1): 79-82.

Willmott CJ, Robeson SM, Matsuura K (2012). Short Communication. A refined index of model performance. International Journal of Climatology, 32(13): 2088-2094.

Yalçın SR, Usta S (1992). Çinko uygulamasının mısır bitkisinin gelișmesi ile çinko, demir, mangan ve bakır kapsamları üzerine etkisi. Ankara Üniversitesi Ziraat Fakültesi Yıllığı, 4(1): 195-204. 